\title{
Understanding the Construction of the Teaching Discourse in an On-Line Environment
}

\author{
Juan Silva ${ }^{1}$ \\ ${ }^{1}$ Departament of Education, University of Santiago, Santiago, Chile \\ Correspondence: Juan Silva, Departament of Education, Center CIIET University of Santiago, Casilla 18 \\ Sucursal Matucana, Santiago, Chile. Tel: 56-227-180-340. E-mail: juan.silva@usach.cl
}

\author{
Received: November 27, 2012 Accepted: December 17, 2012 Online Published: February 4, 2013 \\ doi:10.5539/ies.v6n3p143 URL: http://dx.doi.org/10.5539/ies.v6n3p143
}

\begin{abstract}
The study of interactions regarding on-line environments for education is an area of research that has being developing during the last years in order to know the type of interactions that take place in discussion forums. Interactions analysis is important in order to know and to understand knowledge construction process in a virtual space. Qualitative and quantitative methodologies are used for the analysis of these interactions. This article presents the study of the interactions in a virtual learning environment for pedagogical training. The analysis of the interactions within a discussion forum is described from the interventions of the tutor and the participating teachers; messages and unit topics are used as analysis units and, in order to gain reliability, percentages are established with experts.
\end{abstract}

Keywords: virtual learning environment, analysis of interactions, teacher training, e-learning

\section{Introduction}

As the information and communication technologies (ICT) become more interactive and collaborative, new opportunities arise to create learning experiences. The use of the interactive potential of ICT allows relieving methodological proposals which, pedagogically, have years of development. Thus, the majority of these virtual training experiences focused in collaborative work and on-line construction of knowledge respond to theoretical frameworks centered in constructivism, especially in social constructivism.

Virtual learning environment (VLE) are spaces based on a communication system mediated through a computer in order to facilitate interaction between participants and tutors. This interaction is a key aspect in educational processes framed within the social construction of knowledge (Garrison \& Anderson, 2005). In a virtual space that favors the construction of on-line knowledge, interactions are crucial for achieving quality learning (Schrire, 2006, Stacey \& Rice, 2002). The VLE are preferably used in the training of graduate and post graduate students, though they are becoming important opportunities to help professional development, which is to say, the continuous training of teachers. Thus, the need to analyze virtual interactions in the private context of the training of this particular kind of professionals becomes stronger; investigations regarding interactions and collaborative work are addressed with different methodologies and reliability levels (De Wever et. al. 2006).

The article is framed within aresearch (Note 1) that seeks to know and to characterize interactions within a VLE meant for the training of elementary teachers. To this end, this research approaches the interactions made by the tutor and the participants in this VLE as part of a concrete experience. Both, the observed experience and the methodology used are presented to quantify and to qualify the tutor's and the participants' interventions.

These interventions, both the tutor's and the participants' were first quantified and then qualitatively characterized from three different points of view: a) categorization of the tutorial and the participants' interventions; b) the type of interaction in which the intervention is given: with the class, the tutor or in general and c) the nature of the intervention construction: personal or collaborative.

The problem of reliability and validation in the categorization process and analysis has been tackled through a triangulation process during the creation and analysis of the categories. Messages and thematic units are used as analysis units.The consensus percentage agreement with experts is used for reliability purposes. 


\section{Literature Review}

\subsection{ICT and Communication}

The effects of ICT in the communicative aspects are so relevant that all cases of communication, synchronous or asynchronous, executed through the use of technologicalresources are called "Computer-mediated communication" (CMC). The investigations have shown that computer-mediated communication can affect communication models, organizational systems, society and identity in general (Dahlberg, 2004). These communicative moments facilitate placing in common ideas, sharing and reflecting them, as well as to develop cooperative and/or collaborative work and to receive feedback and orientation from the tutor (Cook, 2002; Nussbaum et al., 2004; Murphy et al, 1998). These communicative tools properly inserted and well attended in the processes of teaching or training can favor collaboration. The advantages of the on-line collaborative learning are well known. However, it is also knownthat because of several reasons, the implemented experiences reach different levels of success (Macdonald, 2003).

The discussion forum is one of the communicative tools (Computer-mediated Conference). It is an asynchronous communication modality that allows dialog using written text as a base (Ryan, et. al, 2000). The discussion forum has a well-known potential to transform the teaching-learning processes, making a group discussion possible as well as the access of other participants to some socialization and communication (Salmon, 2000; Harasim et.al, 2000; Bates, 1995).

The use of discussion forum allows creating learning environments based on sociocultural constructivist models, enabling collaborative work and knowledge construction within a learning community. These communication tools play an important role helping participants to reduce the lack of interaction -a difficulty that used to be considered a feature of distance education-, allowing interactions between the students and the professor as well as among students (Ryan et al., 2000, Salmon 2000; Wallace, 2001). The interactions in virtual spaces are the base to generate formative instances based on collaborative computer-mediated learning.

\subsection{Virtual Interactions}

ICT pave the way for facilitating and making communication possible, but many times this is given only at a participation level, which is not a synonym of interaction. It is necessary to distinguish between these two concepts that sometimes are used or taken as synonyms. "While we take participation as the presence and virtual contribution of the professor, but above all, of the student, interaction adds the answer and linkage of mutual comprehension carried out through language" (Barberá and Badia, 2004, p.26). Interaction is vital for knowledge construction through the exchange of messages with other participants and the tutor. Centered in the discussion topics, messages are initially built from personal experience and then enriched with the contributions of the others. Participation, on the other hand, simply supposes "to be there and to intervene", but it does not require an answer neither necessarily causes one. Several investigations have shown that a great part of the messages exchanged through discussion are rather situated in the level of participation more than in interaction (Cabero, 2004). It is necessary to relocate virtual interaction in some entirely educational psychology coordinates in order to contribute to the improvement of teaching and learning processes in virtual environments (Barberá and Badia, 2004).

Technologies facilitate interactions, which is important in theon-line teaching and learning processes that promote collaboration and social construction of knowledge, being the key to achieve quality learning (Garcia Aretio, 2003; Stacey \& Rice, 2002; Schire, 2006). The communicative potential of the ICT incorporates the decisive characteristic of the formal educational process: Interaction among tutors, students and contents (Garrison \& Anderson 2005). The communicative potential of the ICT allows approaching the positive aspects that interactions have in on-ground learning environments to this other teaching modality, while incorporating the positive aspects of the on-line interaction. Nevertheless, it is necessary to keep in mind that technology neither creates communication nor learning by its own (Gros, 2007).

The asynchronous interaction in virtual spaces is different from the interaction that occurs in an on ground class; it has some peculiarities that differ from a face to face interaction but it is neither better nor worse. It is true that on-line interaction loses in non-verbal aspects, but it wins in time and space flexibility; it certainly loses emotionality, but wins in its content continuity. Space and time dimensions in which these interactions are produced suggest different ways of supporting knowledge construction (Barberà, \&Badia, 2004).

There are many factors that affect the frequency and quality of interaction in a virtual space (Barberà, Badia\&Momino, 2001). Those factors cluster in three areas: The professor, in whom the control, the ability, aids provided, and his social presence are emphasized; the student andhis previous knowledge, the sense and meaning 
he gives to the task and the evaluation method; the taskand its characteristics, the size of the virtual classroom and the period of time required.

In more globalized distance learning experiences or in countries with different cultures, it is important to know and to address factors such as discussion design and its subsequent moderation; students' cultural differences shown in discrepancies such as learning styles, communicative ways and styles, social interaction, use of language, etc.

Within the factors of success for the asynchronous on-line learning environments, there are three that significantly contribute to favor interaction, these are: A transparent interface; an instructor who frequently and constructively interact with the students, and a valued dynamic discussion (Swan et al. 2000). The role of the tutor is crucial in the success of an on-line training experience, because he develops tasks in administrative, social, technical, and pedagogical aspects. Particularly important is the role of the discussion moderator, which is intended for promoting collaborative learning inside a learning community. The frequency and quality of the interventions in a discussion forum will be in great measure defined by the moderating activities performed by the tutor (Berge, 1995; Salmon, 2000). Finally, the platform should have certain characteristics and spaces that promote interaction, including environments differentiated by different actions of different nature, such as social, pedagogical, technical and administrative (Pérez, 2004).

\subsection{Analysis of the Interactions}

The interactions analysis given in on-line discussion spaces seeks to understand how the teaching and learning process in a collaborative virtual space is produced. It is necessary to analyze on-line discussions in order to determine how social construction of knowledge is produced through them. "In order to show the processes of collaborative learning to the investigators, interactions among participants must be available for their careful study while investigators must be able to properly interpret them" (Stahl 2002, 178 in Puntambekar and Luckin 2003).

In on-line discussion forums, the texts that show these interactions are electronically available to be analyzed from several points of view, for example: from the investigators', as well as the teachers' or tutors' of the course or by those developing these training experiences (Rourtke et.al, 2005; De Benito and Pérez, 2003; Naidu and Järvellä, 2006). In spite the fact that texts with the interactions are electronically available, their analysis is not trivial; at first it may seem simple, but it is a complex, time consuming task that requires clear methodological and theoretical frameworks (Rourtke et al., 2005). One complexity of the interactions analysis in the VLS arises from the need to establish messages analysis systems in order to understand interactions and how they are produced. Tools to analyze the speech produced in asynchronous interaction environments have had an interesting evolution, needed to understand the investigation methodology in this environment (Gros, 2007).

In order to describe this kind of interaction, especially the one between the teacher and his students and among students themselves, several models that allow categorizing them have been developed, whether in a social or cognitive context. These models are supported in the pedagogical conceptions that their authors subscribe regarding on-line learning. In Gros\& Silva (2006), a collection of the main models for the on-line interaction analysis is presented; they were developed during the two last decades. The analyzed models were: Henri, Bullen, Gunawardena and collaborators, Garrison and Anderson, Scardamalia and Bereiter, Järvelä and Häkkinen among others. Theproposed categorization models were created by several investigators or groups of investigators. They were created from specific theoretical frameworks, some of them more explicitly than the others. In all these studies there are alternatives and variations, especially regarding the analysis units used: For example, in some cases, thematic units were chosen (Henri). In others, complete messages were analyzed (Gunawardena), while in the analysis of Jäverlä, all the discussion is just one analysis unit.

A review and synthesis of the investigation on the interaction analysis in on-line contexts concludes with the following results (Wallace 2003 in Marcelo \&Perera, 2004):

- The investigators have been developing models for the analysis of on-line teaching and learning, through the study of the on-line debates records. These models have incorporated cognitive, social and metacognitive aspects. Some investigations have tried to investigate the students' progression in levels of thought in their on-line discussions.

- When using these models, investigators have found that guiding students so they can pass from sharing and exchanging ideas to knowledge construction is a complex task in on-line teaching. Students are willing to share ideas, but not to deepen in knowledge through debate. 
- On-line professors take different roles: They facilitate or moderate debates, respond individually to students and to the class as a whole, negotiate the contents flow through tasks, etc.

- There are multiple evidences that emphasize the importance of social interaction, as well as the presence of the professor in on-line classes.

- The on-line community is a very important variable in the VLS. Although the importance of its role is acknowledged, there aren't enough studies about the way it happens.

\section{Methodology}

By 2005 the implementation of the Enlaces Network (Note 2) had allowed $88 \%$ of primary education centers and $85 \%$ of high schools to have computer technology, while $82.5 \%$ of acting teachers were digitally alphabetized and qualified for integrating ICT in their curriculum (Enlaces, 2005). From this basis, the Experimentation Improvement and Pedagogical Investigation Center (CPEIP) of the Ministry of Education of Chile (MINEDUC) has carried out five massive experiences of distance training for teachers in several areas, such as mathematical, sciences and English (Arellano and Cerda, 2006). The evaluation CPEIP assesses from these experiences reflects positive results regarding evaluation of the courses and passing levels. Nevertheless, interactive processes are negatively perceived since individual processes with scarce use of the interactive spaces is noticed; teachers prefer face to face interactions (Borrero, 2006).

To improve interactions in on-line training experiences, it is necessary to understand how this interactive process develops. This is why we engaged in an investigation whose general objective was:To describe interactions in a virtual learning environment for the continuous training of elementary teachers. This should be achieved from the general assessment of the formative experience; the appraisal of the tutor's role, the use and evaluation of interactive spaces provided by the platform and the characterization of the tutor andthe participating teachers' interventions in the discussion forum. As mentioned above, this article centers in this last aspect.

In 2006, the Comenius Center of the University of Santiago de Chile conducted the course "Geometry.cl: Learning Geometry by Creating Solutions." It was aimed at teachers working in the second cycle of Primary Education. This course was carried out in a B-learning modality, it was funded by the Ministry of Education and 786 teachers from all the country participated in it (Silva, 2006). The total of participants within the course was subdivided in 26 groups of about 30 teachers each.

The investigation was conducted through monitoring one of these groups, the one that was composed of 38 teachers who work in the second cycle of primary education of the Chilean educational system (5th to 8th grade). Some figures: $84.2 \%$ of the participants were women; $55.3 \%$ had more than 12 years of teaching experience; $68.4 \%$ of the participants weremerely primary education teachers which imply they do not have a specific training in mathematics; a total of $84.2 \%$ worked as classroom teachers. Regarding the use of ICT, participants show a good handling level as for navigation, information and resources search on the Internet. Nevertheless, in discussion environments and conversation as forums or debate, teachers show little or no handling at all. $63.2 \%$ of the participating teachers did not record distance experiences through Internet. Regarding the place for entering in the platform, $63.2 \%$ entered from home and $73.7 \%$ from their workplace.

The tutor of this monitored group is a high school math teacher with extensive experience in the area, who has also been a tutor in two previous courses and he was well evaluated by the participants. Within the coordinator team of the experience, he was the "tutor of tutors".

An holistic approach is necessary for the comprehension of the interaction processes and on-line knowledge construction that allows analyzing the different dimensions that intervene in such processes: interaction patterns, speech characteristics, how the process of knowledge construction is produced and what should the role of the tutor in these interventions be (Gros, 2007).

The quantitative aspects provided data related to the number of sent messages, the subject matter of the interventions and the intervention type, among others. This allowed having a very general idea of the quantities and interactions flows, without entering into interaction content neither into the consequences regarding students' learning (Shire, 2006). It is required to analyze the interactions content and the way in which these are built. Only through the mixture of qualitative and quantitative methods, the collaborative on-line construction of knowledge can be well described (Hmelo-Silver, 2003; Puntambekar\&Luckin, 2003).

In order to make reliable the results and the conclusions gathered from this interactions study, Reliability among evaluators is used, that is to say, the degree in which different evaluators assign a same unit of analysis the same category. This aspect is very important in order to give validity to the results obtained and the conclusions gathered from them. As long as a contents analysis study presents its reliability data, the community of 
investigators will be able to cite and to use these discoveries and/or results with a scientific support. The percentage agreement is one of the simplest and highly used methods to measure reliability, which reports the number of agreements relating to the total analysis units categorized between the investigator and the experts.

The work methodology used in the investigation took into account qualitative and quantitative elements in order to cover different aspects previously considered. These aspects were developed in different moments of the research and involve different processes and actors. Table 1 refers to the methodological aspects and the used methodologies:

Table 1. Methodological aspects

\begin{tabular}{|c|c|}
\hline Aspects & Methodological elements \\
\hline $\begin{array}{l}\text { Quantification of } \\
\text { participations }\end{array}$ & $\begin{array}{l}\text { - Quantification and record of the participating teachers' interventions in } \\
\text { interactive spaces. } \\
\text { - Quantification and record of interventions of the participating teachers } \\
\text { and tutor in interactive spaces. }\end{array}$ \\
\hline $\begin{array}{l}\text { Characterization of the } \\
\text { tutor's and the participating } \\
\text { teachers' interventions. }\end{array}$ & $\begin{array}{l}\text { - Interventions analysis categories definition of the tutor and participating } \\
\text { teachers. } \\
\text { - } \quad \text { Validation of the categories with experts. } \\
\text { - } \quad \text { Categorization in the three intervention forums of the tutor and } \\
\text { participating teachers. } \\
\text { - } \quad \text { Validation with experts in one of the forums. } \\
\text { - } \quad \text { Analysis of the tutor's and the participating teachers' interventions. }\end{array}$ \\
\hline $\begin{array}{l}\text { Interaction of the } \\
\text { interventions and nature of } \\
\text { their texts. }\end{array}$ & $\begin{array}{l}\text { - } \quad \text { The type of interaction was defined: tutor, course or general. } \\
\text { - } \quad \text { The nature of the texts was defined: personal or collaborative. } \\
\text { - } \quad \text { These two identifiers were added for each intervention of the } \\
\text { participating teachers in the three forums. }\end{array}$ \\
\hline
\end{tabular}

The participations of the tutor and the participating teachers in the different interactive spaces given by the course were quantified with the statistics that the Moodle platform delivers regarding interventions in these spaces.

To analyze the interventions of the tutor and the participants in the discussion forum, messages and thematic units were taken as analysis units, prioritizing analysis units that describe a same idea. Afterwards, using this criterion, the analysis unit would be the message in some cases while in others it would be paragraphs or phrases.

Categories were built to analyze the tutor's interventions (Table 2) as well as the participants' (Table 3), using deductive and inductive methods. This implied to use, for the construction of analysis categories, elements of literature referred to interactions and to the role the tutor in virtual spaces of learning have, as well as the observance of the interventions experience under development. Protocols of existing categories were not used because they were not adjusted to interactions in the investigation context, which is educational interaction. Most of the protocols of existing categorization concern regulated training environments for degree and post degree levels. These categories were validated with experts whose purpose was having a clear definition of them and their application at the time of categorizing. For this effect, experts received an instrument with the categories and application examples of them. The categories were validated with examples taken from the three forums. 
Table 2. Tutorial interventions Categories

\begin{tabular}{ll}
\hline Category & \\
\hline Beginning of the debate & $\begin{array}{l}\text { The discussion topic is presented as well as the guiding questions that will make the } \\
\text { debate come to life. } \\
\text { What was discussed is summarized emphasizing the main contributions and } \\
\text { reorienting the discussion with new questioning. } \\
\text { Partial synthesis }\end{array}$ \\
$\begin{array}{l}\text { What was discussed is summarized, emphasizing the main contribution and the topic } \\
\text { is closed. }\end{array}$ \\
$\begin{array}{l}\text { The participant is invited to express in detail his opinions about the discussed topics. } \\
\text { Background }\end{array}$ \\
$\begin{array}{l}\text { Participants are oriented and motivated to think about how the course project can } \\
\text { contribute to their professional development }\end{array}$ \\
$\begin{array}{l}\text { Promoting interventions oriented to facilitate the participants to share experiences and } \\
\text { information that could be useful to other participants. } \\
\text { information } \\
\text { Orientation }\end{array}$ \\
$\begin{array}{l}\text { Interventions that lead the participant into the course project and in the use of } \\
\text { resources. }\end{array}$ \\
$\begin{array}{l}\text { Interventions with a positive reaction regarding participant's interventions, } \\
\text { congratulating him and encouraging him to continue to be engaged in the forum. }\end{array}$
\end{tabular}

Table 3. Participating Interventions Categories

\begin{tabular}{ll}
\hline Category & Description \\
\hline Theoretical elements & $\begin{array}{l}\text { Theoretical elements related to learning theories and the cognitive bases related to } \\
\text { the contents of the course are presented. }\end{array}$ \\
Previous experiences & $\begin{array}{l}\text { Intervention comes from the teachers' own experiences regarding their work or } \\
\text { from the ones told by the participants. } \\
\text { The perception of the course and its influence in their professional development } \\
\text { Perception of the course }\end{array}$ \\
are presented. & $\begin{array}{l}\text { It's the transfer to the classroom of the several aspects of the course, such as: } \\
\text { activities, material and methodological strategies, among others. }\end{array}$ \\
New training needs & $\begin{array}{l}\text { Students show a need of a greater educational training related to the contents of the } \\
\text { course, didactic strategies for contents teaching, and the control and integration of }\end{array}$ \\
ICT resources. & $\begin{array}{l}\text { They are structural problems that hinder educational practice and innovations } \\
\text { deployment that do not directly depend on the teacher, such as lack of } \\
\text { technological infrastructure, time, material and no Faculty Board support. }\end{array}$ \\
\hline
\end{tabular}

In the categorization of tutorial and participants' interventions, a forum categorized by investigators and experts was used. At first, the percentage agreement was taken as a reliability factor, reaching an average of $72.2 \%$ for tutorial interventions and $69.7 \%$ for participants' intervention. After contrasting the differences among evaluators, reliability was directed toward a consensus percentageagreement, reaching $80.3 \%$ for tutorial interventions and $78.3 \%$ for participants' interventions. At the beginning, the other two forums were independently categorized by the investigated teachers. Then, from the criteria given by the validation with experts, they were once again categorized to unify the categorization in the three forums.

Two elements were considered interesting to analyze in light of the analysis of the texts regarding participants' interventions: To whom the interventions aimed at and what the personal or collaborative nature of these constructions was. These two aspects were incorporated to each already categorized analysis unit.

In order to determine the type of interaction, the recipient of the intervention was taken into account: whether it was the tutor, the class -one participant or all of them- and in general. The first two correspond to an interaction context, but not the third one, since it is not possible to determine a possible recipient. Table 4 shows the interaction type, its description and some examples. 
Table 4. Type of interaction of the interventions of teachers participants

\begin{tabular}{|c|c|c|}
\hline $\begin{array}{c}\text { Type of } \\
\text { Interaction }\end{array}$ & Description & Some examples \\
\hline Tutor & $\begin{array}{l}\text { Interventions directed to the } \\
\text { tutor }\end{array}$ & $\begin{array}{ll}- & \text { Dear Professor } \\
- & \text { Professor } \\
- & \text { Ricardo (name of the tutor) } \\
- & \text { Dear Ricardo } \\
- & \text { Hello Ricardo }\end{array}$ \\
\hline Course & $\begin{array}{l}\text { Interventions directed to another } \\
\text { participant or to the course } \\
\text { group }\end{array}$ & $\begin{array}{ll}- & \text { Dearcolleagues } \\
- & \text { Dearparticipant } \\
- & \text { Hello (participantname) } \\
- & \text { I was interested in your reflection ... } \\
- & \text { I don't really agree with you... } \\
- & \text { I think you are absolutely right... } \\
- & \begin{array}{l}\text { After reading the comment of (name of the } \\
\text { participant)... } \\
\text { Regarding the opinion of (name of the } \\
\text { participant)... }\end{array}\end{array}$ \\
\hline General & $\begin{array}{l}\text { Interventions in which is not } \\
\text { possible to identify the receiver }\end{array}$ & $\begin{array}{ll}\text { - } & \text { Geometry should be taught because... } \\
\text { - } & \text { I use TICsfor ... } \\
\text { - } & \text { I think it's important to use specific material ... }\end{array}$ \\
\hline
\end{tabular}

Regarding the nature of the interventions it was considered whether the intervention was executed based on personal arguments or on previous participations of the tutor or other participants, thus establishing if the intervention of the participant teachers was personal or collaborative. Table 5 shows the intervention construction type, its description and some examples.

Table 5. Nature of the interventions of the participating teachers

\begin{tabular}{|c|c|c|}
\hline $\begin{array}{l}\text { Nature of } \\
\text { theintervention }\end{array}$ & Description & Someexamples \\
\hline Personal & $\begin{array}{l}\text { Interventions that are built from a } \\
\text { personal approach do not take into } \\
\text { account previous interventions of other } \\
\text { participating teachers, but they describe } \\
\text { an opinion or personal beliefs } \\
\text { experience. }\end{array}$ & $\begin{array}{ll}- & \text { I think } \\
- & \text { I reckon } \\
- & \text { I believe } \\
- & \text { Accordingtomyexperience } \\
- & \text { In myview } \\
- & \text { I consider }\end{array}$ \\
\hline Collaborative & $\begin{array}{l}\text { Interventions based on the contributions } \\
\text { of other participating teachers. }\end{array}$ & $\begin{array}{ll}- & \text { As it has been mentioned before } \\
- & \text { As (name of the participant) mentioned.... } \\
- & \text { I agree with the opinion of... } \\
- & \text { I think the same as you ... } \\
- & \text { I have read your intervention and I agree } \\
\text { in... } \\
\text { - } & \text { I agree with the opinion of ..., } \\
- & \text { I disagree with the opinion of..., } \\
- & \text { It thought about giving an opinion, but } \\
& \text { what has (participating name) just said } \\
& \text { represents me... } \\
- & \text { I don't agree with the opinion of... }\end{array}$ \\
\hline
\end{tabular}

All qualitative aspects related to the interventions analysis from the tutor's and the participating teachers' categorization, as well as the nature and collaborative aspect of them were conducted using the software for qualitative analysis ATLAS-TI; converting the results into tables that show the presence of each one of the categories used at a general level and of each forum. Likewise, it was also possible to look at the cluster of texts of a specific category to discover unique aspects of it and to associate it with proper examples. 


\section{Finding and Discussion}

\subsection{Intervention Quantification}

Discussion forums have three moments: presentation of the topic; execution of a summary, reorientation of the debate and closure with a final synthesis.

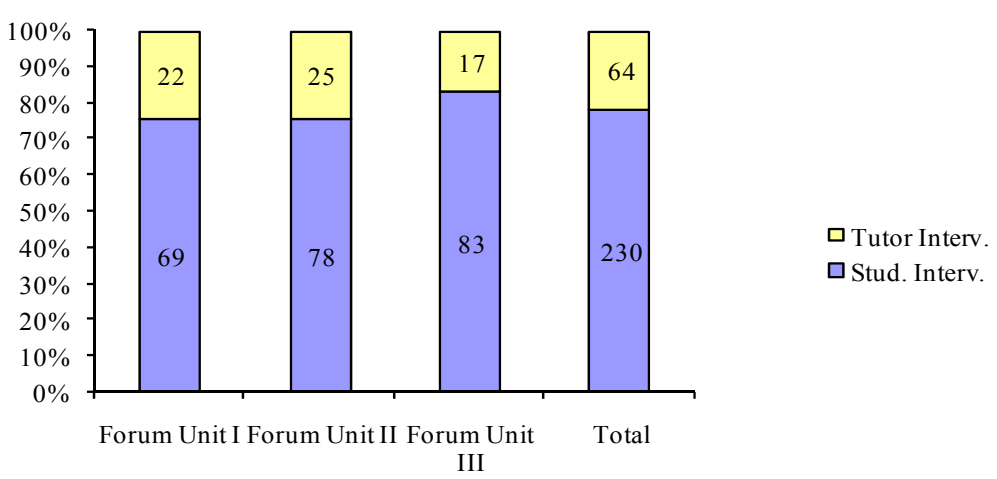

Figure 1. Interventions in discussion forums

In the three forums (graphic 1) a total of 294 interventions were recorded, $78.2 \%$ of them correspond to participants and $21.8 \%$ to the tutor. The participants' interventions grow insofar as the forums develop while the tutor's interventions diminish. In general, the interventions of the tutor do not surpass the $25 \%$ suggested in literature.

\subsection{Characterization of Tutorial Interventions in Discussion Forum}

So far, 67 tutorial interventions in the three discussion forums were categorized, assigning them an assembly of 73 categories in total, which is to say that $8.2 \%$ (6) of them have two categories.

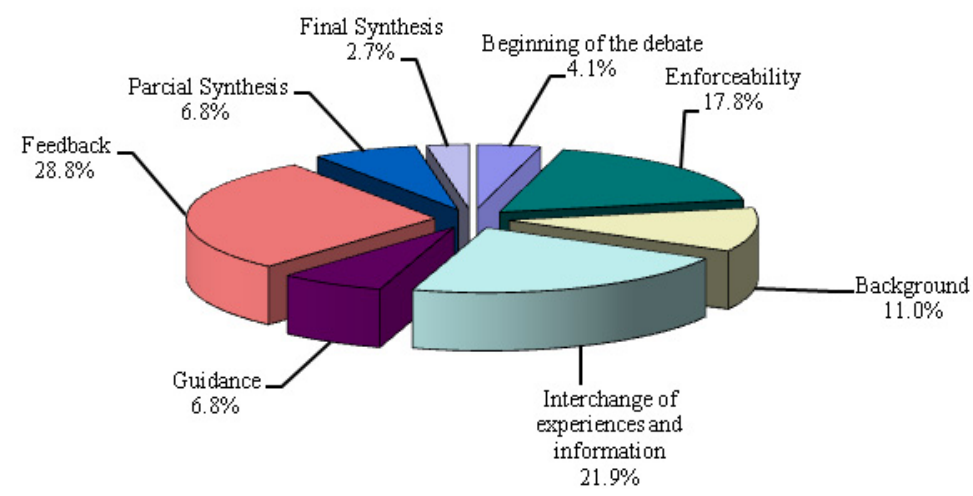

Figure 2. Categorization tutor interventions

On the other hand, two large families appear when the intervention type is analyzed. One of these families is the intervention aiming at the group course that corresponds to the beginning of the debate, the partial synthesis and the final synthesis, and it represents a $13.7 \%$ of the interventions. The second family is the $87.3 \%$ of the remaining intervention given in an interaction context between the tutor and a participant. 
Interventions aiming at the group course aren't very frequent, since they appear only once or twice in each forum. That is how beginning of the debatewith $4.1 \%$ is presented at the beginning to introduce the discussion, to carry out summaries such as partial synthesis, with $6.8 \%$ and to conduct a general summary closing the discussion in final synthesis with $2.7 \%$. These categories are related to specific moments of the forum activities. They are interventions aiming at the group course which during the Beginning of the debate and final synthesis of each forum can be presented only one time at the most.

Interventions aiming at one participant are presented in the forums very often and in several ways, according to their development. This is how feedback, which is congratulating and encouraging students to continue participating in the forum concentrates a $28.8 \%$. The exchange of experiences and informationrepresents a $21.9 \%$. Enforceability, which aims at thinking of how the work of the course can contribute professional development concentrates a 17,8\%. Background, which aims at creating greater arguments supporting students' interventions represents a $11.0 \%$ and orientation delivers $a 6.8 \%$.

\subsection{Interventions of Participants Categorization}

So far, 236 interventions of the participants in the three discussion forums were categorized, assigning them a cluster of 276 categories, which is to say that a $16.9 \%$ of the interventions belong to two categories. The categorization within the three discussion forums regarding participants' interventions is shown in the following graphic. It shows the category, a brief description and the percentage in which the categorized intervention assembly is presented.

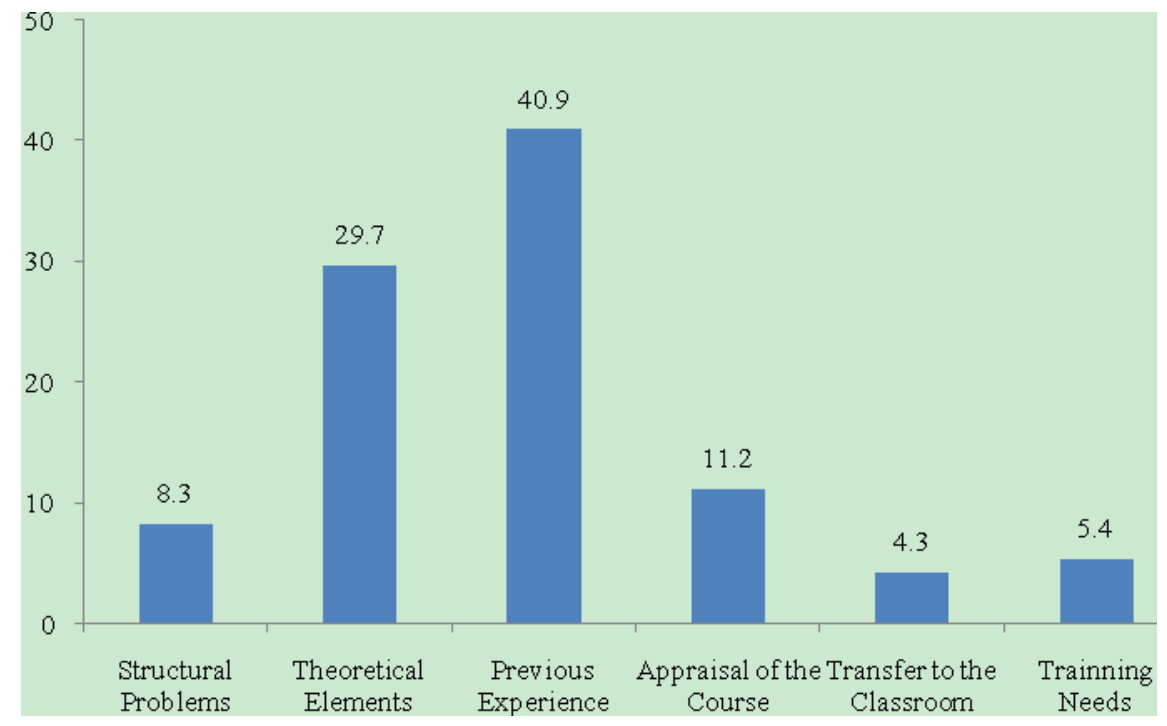

Figure 3. Categorization participants' interventions

Upon analyzing the categorization of the participants' interventions in the cluster of the three discussion forums it is observed that the categories Previous Experience and Theoretical Elements, concentrate most of the participants' interventions with $40.9 \%$ and $29.7 \%$ respectively. These two categories concentrate the $70.6 \%$ of the total, implying that most of the educational discourse in the discussion forums is built from previous educational experience or theoretical elements, conditions that allow the teacher to support his interventions, describing beliefs and conceptions ingrained in them. The category Appreciation of the course presented a 11.2\%. This category is related to the effects of the course in the educational training process seen from the perspective of methodological changes, contents management and incorporation of several resources as well as the experience of training with peers in a virtual space.

There is an assembly of three categoriespresent in percentages lower than $10 \%$. In this setting, Structural Problems appear with the $8,4 \%$ and it is related to the difficulties found within the school system, such as lack of time, lack of resources or access to technology and also to problems related to the practice of educational profession, Formative Needs with 5,4\%, corresponds to the need that the teacher finds when it comes to training access in order to overcome his lacking of contents management and teaching methodologies; these two categories directly influence the current teaching practices. Besides, Transfer to the Classroom, with $4.3 \%$, 
relates to classroom transfer of the proposals of the course regarding activities, material and resources, reflected in the proposed methodologies. It is presented in two ways: Concrete transfers and planning of transfer.

\subsection{Type of Interaction}

We seek to identify the type of interaction the intervention responds, so it was considered appropriate to determine the recipient of it: tutor or course which can consider the group as a whole or just one participant. Generally, they are interventions where it is not possible to determine a recipient. The first two correspond to an interaction context, but the third doesn't. In order to do so, this identifier was added to each intervention already categorized.

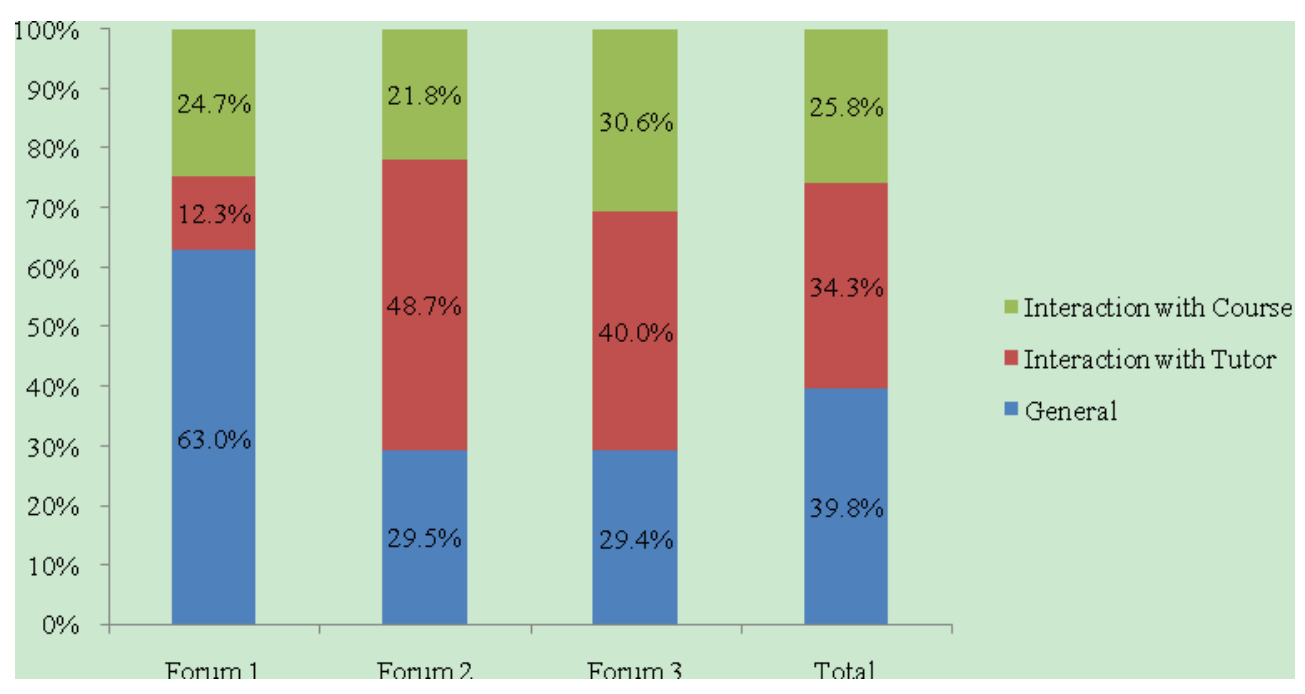

Figure 4. Type of Interaction

At a Global level, it is shown that $60.1 \%$ of the interventions happen in an interaction context with the tutor or with the course, while the remaining $39.8 \%$ belongs to general interventions.

Interactions to the tutor represent the $34.3 \%$ of the total interventions, distinguishing two ways to address him: By his name, "Ricardo" or by his title, "Professor". No interventions in which participants called him "Tutor" are observed.

Interactions aiming at the course represent a $25.8 \%$ which can be classified in two large "families". One family is the one in which the other recipient or the collective recipient is directly mentioned, while in the other family the receiver is not mentioned, but it is easy to deduce interactions are aiming at one specific participant or at the collective recipient.

\subsection{Nature of the Interventions}

An additional look on the interventions is related to their nature: personal, which mean built on the base of personal arguments not linked to previous interventions; and collective, in which interventions come precisely from previous interventions. 


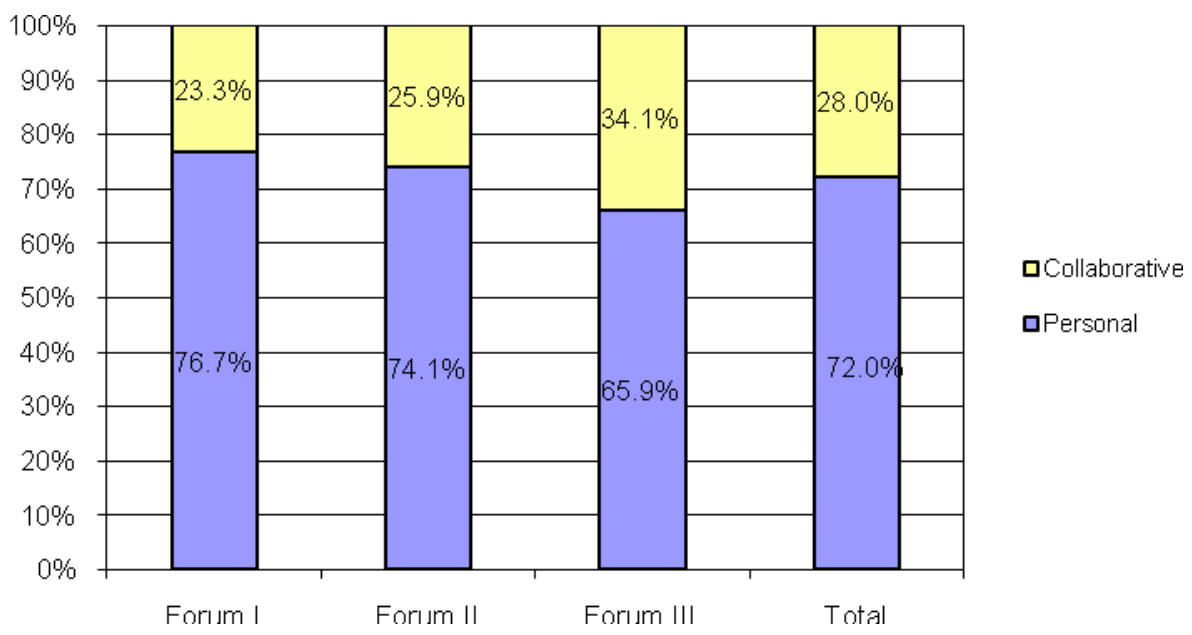

Figure 5. Nature of the Interventions

It is observed that in general, $72 \%$ of the participants' interventions are personal and only a $28 \%$ is collaborative. The collaborative interventions refer to previous contribution of another participant and are presented in a growing rate in the forums.

\section{Summary and Suggestion}

The categorization of tutorial interventions shows that the major effort of the tutor's interventions focuses on favoring interaction with the participants; nevertheless, there are aspects conducted in key moments for the development of the debate, such as initiate it, conduct a partial and a final synthesis. In the case of the participants, their interventions come from theoretical elements or from their educational experience.

From the interactions perspective, a majority percentage of the interventions corresponds to interaction, whether with the tutor or with the group -the whole group or one specific participant-. The level of interaction grows from the first to the third forum. Investigating this type of interaction is a prominent aspect because there are several researches that report interventions where most of the interaction is between the tutor and the participants, not necessarily among peers (Cabero 2004; Adrián, 2003). Attesting for the nature of intervention is an important aspect to understand how close the teacher is involved in his work within a community of virtual learning where he can contribute with personal interventions, but also construct from the interventions of other participating teachers. These indicators also tell a development tracking of the discussion by the participating teachers, since it is necessary to read the interventions of the others in order to construct from them. Literature on this topic shows that interaction among peers grows during the course to the extent that they develop a commitment with it and with their companions (Lipponnen, 2002; Macdonald, 2003).

One of the objectives of these training experiences is to create learning communities. Therefore it is required to participate with others in a collaborative knowledge construction. In this context, it is observed that at the beginning, participants' interventions are personal and gradually become more collaborative. One of the outstanding aspects in the investigation regarding on-line discussions is this capacity to construct knowledge on-line (Harasim et al., 2000; Murphy et al., 1998; Salmon, 2000). However, several investigations also show that this collaboration is not simple and it is normal to find discussion forums built from personal contributions (Macdonald, 2003; Lipponen et al., 2002; Cabero, 2004).

The analysis methodology we used supposes a categorization process that implies a double analysis. First, once the categories have been established, the investigator should submit them to the analysis of other expert investigators in the field; once the categories are analyzed and contrasted, the investigator should analyze the messages based on them. There is a second level of contrasting that incorporates the methodology we present, it involves validating this second level of analysis with experts. That is to say, not only validate the categories, but also their application. This second level of validation allows ensuring a consensus in the data application and interpretation. In this investigation, regarding tutorial interventions, an average consensus percentage agreement of $80.3 \%$ is achieved, while regarding participants' interventions an average consensus percentage agreement of 
$78.3 \%$ is achieved. The two remaining forums were analyzed with these reliability values in order to dispose tutors and participants interactions in this teacher training experience.

Despite the precautions taken to favor interactions in virtual learning communities it is not possible to leave aside the social and cultural aspects that make teachers conceive their profession as an isolated action, even inside the same school; this is stated in the interventions they give since they are within a more a personal than collaborative context. However, this tendency tends to change during the course.

It is presumed that as long as the teachers systematically use the virtual communication spaces, interventions will improve in quantity and quality. It is advisable that initial teaching training include this kind of learning experiences, taking advantage of the fact that the interactive culture is more extended among young people.

This investigation presents concrete results regarding the analysis of teaching interactions in virtual spaces. From this research new investigations can be conducted to answer further questions such as: What results would be obtained with teachers from other curriculum sectors, closer to the use of language? What will happen with foreign teachers? How would pedagogy students inserted in the ICT communicative culture behave? In all these cases it would be appropriate to make the following questions: Will the proposed analysis categories be useful? Will it be similar or different levels of interaction and personal or collaborative constructions? Who and how many will interact and collaborate?

\section{References}

Adrián, M. (2003, June). Participación e interacción en conferencias asíncronas en red: Análisis de una experiencia en la formación del profesorado a distancia. Communication presented in the IV Congreso Multimedia Educativo, ICE-Universidad de Barcelona, Barcelona.

Arellano, M., \& Cerda, A. (Ed.). (2006). Formación continua de docentes: Un camino para compartir. Santiago: Maval.

Barberà, E., \& Badia, A. (2004). Educar con aulas virtuales: Orientaciones para la innovación en el proceso de enseñanza y aprendizaje. Madrid: A. Machado.

Barberà, E. (Coord)., Badia, A., \& Momino, J. M. (2001). La incógnita de la educación a distancia. Barcelona: ICE Universidad de Barcelona/Horsori.

Berge, Z. L. (1995). Facilitating Computer Conferencing: Recommendations From the Field. Educational Technology, 35(1), 22-30. Retrieved August 18, 2003, from http://www.emoderators.com/moderators/teach_online.html

Borrero, A. (2006). Reflexiones acerca de la experiencia de Formación Continua de Docentes por medio de TIC realizado por el Ministerio de Educación. In Arellano, M., \& Cerda, A. (Ed.), Formacióncontinua de docentes: Un camino para compartir (pp 235-242). Santiago:Maval.

Cabero, J. (2004). Reflexiones sobre las tecnologías como instrumentos culturales. In Martínez, F., \& Prendes, M. (Coord), Nuevas tecnologías y Educación (pp. 15-19). Madrid: Pearson.

Cook, J. (2002). The Role of Dialogue in Computer-Based Learning and Observing Learning: An Evolutionary Approach to Theory. Journal of Interactive Media in Education, 5. Retrieved from www-jime.open.ac.uk/2002/5

Dahlberg, L. (2004). Internet Research Tracings: Towards Non-Reductionist Methodology. JCMC, 9(3). Retrieved from http://www.ascusc.org/jcmc/vol9/issue3/dahlberg.html

De Wever, B., Schellens, T., Valcke, M., \& Van Keer H. (2006). Content analysis schemes to analyze transcripts of online asynchronous discussion groups: A review. Computers \& Education, 46, 6-28. http://dx.doi.org/10.1016/j.compedu.2005.04.005

Enlaces. (2005). Estadísticas Enlaces 2005. Retrieved from http://www.enlaces.c1/libro/estadisticas.pdf

García Aretio, L. (2003). Comunidades de aprendizaje en entornos virtuales: La comunidad iberoamericana de la CUED. In Barajas M. (coord), La tecnología educativa en la educación superior (pp. 171-199). Madrid:McGraw-Hill.

Garrison, D. R., \& Anderson, T. (2005). El e-learning en el siglo XXI: Investigación y práctica, Barcelona:Octaedro. (Versión original: E-learning in the 21 stcentury, RoutledgeFalmer, 2003).

Gros, B., \& Silva, J. (2006). Metodologías para el análisis de espacios virtuales colaborativos. Revista de Educación a Distancia, 16. Retrieved October, 2006, from http://www.um.es/ead/red/16 
Gros, B. (2007). Tramas, conexiones y artefactos. Barcelona: Octaedro.

Harasim, L., Hiltz, S., Turoff, M., \& Teles, L. (1995). Learning networks. A fiel guide to teaching and learning online. Cambridge (USA): Massachusetts Institute of Technology Press.

Hmelo-Silver, C. (2003). Analyzing collaborative knowledge construction multiple methods for integrated understanding. Computers \& Education, 41(4), 397-420. http://dx.doi.org/10.1016/j.compedu.2003.07.001

Lipponen, L., Rahikainen, M., Hakkarainen, K., \& Palonen, T. (2002). Effective participation and discourse through a computer network: Investigating elementary students computer supported interaction. Journal of Educational Computing Research, 27, 355-384. http://dx.doi.org/10.2190/MGTW-QG1E-G66E-F3UD

Macdonald, J. (2003). Assessing online collaborative learning: Process and product. Computer \& Edutacion, 40(4), 377-391.

Marcelo, C., \& Perera, H. (2004). El análisis de la interacción didáctica en los nuevos ambientes de aprendizaje virtual. Bordón, 56(3), 533-558. http://prometeo.us.es/idea/mie/pub/marcelo/bordon.pdf [2006, Junio 18]

Murphy, K., Drabier, R., \& Epps, M. (1998). A Constructivist Look at Interaction and Collaboration via Computer Conferencing. International Journal of Educational Telecommunications, 4(2/3), 237-261.

Nussbaum, M., Hartley, K. Sinatra, G., Reynolds R., \& Bendixen, L. (2004). Personality Interactions And Scaffolding In On-Line Discussions. Journal Educational Computing Research, 30(1\&2), 113-137. http://dx.doi.org/10.2190/H8P4-QJUF-JXME-6JD8

Pérez, A. (2004). Comunicación mediada por ordenador, estrategias instructiva y tutoría. In Salinas, J., Aguaded, J., \& Cabero, J. (Coords), Tecnologías para la educación (pp. 295-319). Madrid:Alianza.

Puntambekar, S., \& Luckin, R. (2003). Documenting collaborative learning: What should be measured and how? Computers\&Education, 41, 309-311. http://dx.doi.org/10.1016/j.compedu.2003.08.002

Rourke, L., Anderson, T., Garrison D. R., \& Archer, W. (2005). Cuestiones metológicas relativas al análisis de contenidos de las transcripciones de clases por ordenador. In Garrison, D. R., \& Anderson, T. (2005), El e-learning en el siglo XXI: Investigación y práctica (pp. 175-202). Barcelona:Octaedro.

Ryan, S., Scott, B., Freeman, H., \& Patel, D. (2000). The virtual university: The Internet and resoursce-based learning. London: Kogan Page.

Salmon, G. (2000). E-moderating: The key to teaching and learning online, London: Kogan Page.

Schrire, S. (2006). Knowledge building in asynchronous discussion groups: Going beyond quantitative analysis. Computers \& Education, 46, 49-70. http://dx.doi.org/10.1016/j.compedu.2005.04.006

Silva, J. (2006). Formación docente en un espacio virtual de aprendizaje: Una experiencia concreta en el contexto chileno. Universidad de Salamanca. Revista Electrónica Teoría de la Educación y Cultura en la Sociedad de la Información, 7(1). $\quad$ Retrieved from http://www3.usal.es/ teoriaeducacion/rev_numero_07/n7_art_silva.htm

Stacey E., \& Rice, M. (2002). Evaluating an online learning environment. Australian Journal of Educational Technology, 18(3), 323-340.

Swan, K., Shea, P., Fredericksen, E., Pickett, A., Pelz, W., \& Maher, G. (2000). Building knowledge building communities: consistency, contact and communication in virtual classroom. Journal Educational Computing Research, 23(4), 359-381.

Wallace, P. (2001). La Psicología de Internet. Barcelona/Buenos Aires/México: Paidós. [Original version: The Psychology of the Internet, Cambridge University Press: United kingdom, 1999]

\section{Notes}

Note 1. The investigation is called "las interacciones en un entorno virtual de aprendizaje para la formación continua de docentes de enseñanza básica" (Interactions in a virtual environment of learning for the continuous training of primary school teachers) for the doctorate in Education program Multimedia Educational in the University of Barcelona, Spain.

Note 2. Project of the Technological Education Center, dependent of the Ministry of Education of Chile. 